JPPIPA, Vol.6 No.1 2021
Jurnal Penelitian Pendidikan IPA
http://journal.unesa.ac.id/index.php/jppipa

\title{
THE RESULT OF VALIDATION TESTING AND STUDENTS RESPONSE TO GEOSCIENCE STUDENTS WORKSHEETS TO IMPROVE STUDENT SCIENTIFIC WORK AND CONCEPTUAL MASTERY
}

Febriani Sarwendah Asri Nugraheni ${ }^{1}$, Meida Wulan Sari ${ }^{2}$, Icha Kurnia Wati ${ }^{3}$

${ }^{1,2,3}$ Program Studi S-1 Pendidikan IPA, Fakultas Keguruan dan Ilmu Pendidikan, Universitas Sebelas Maret, Indonesia

\begin{abstract}
Geoscience is a study of earth, it is easy to find around everyday student's life. The aim of this research is to develop Geoscience Students Worksheets based on scientific work to enhance students scientific work and conceptual mastery also to test the validity of the Geoscience Students Worksheets through experts appraisal and students response. This reasearch is $\mathrm{R} \& \mathrm{D}$ research using 4D model until Develop stage. Data collection techniques including survey and interview technique. The question in the questionnaire consists on closed ended and open ended, the close ended question it to measure the validity and students response while open ended question for obtaining suggestions from all experts and students. Moreover, interview conducted during preliminary study. There are two validators in this research, they are content and learning media expert with Science Education educational background. In addition, ten students respondents in this research are already took the Geoscience Course last year. Quantitative data was analyzed by comparing the score with certain criteria and qualitative data was analyzed with finding common topics. Validation result and students respon results show that Geoscience Students Worksheets is very valid with score from content expert, learning media expert, and students consecutively $90,01 \%, 85,70 \%$, and $89,4 \%$.
\end{abstract}

Keywords: Students Worksheets, Geoscience, Scientific, Valid

(C) 2021 Universitas Negeri Surabaya

${ }^{1}$ Correspondence Address:

S-1 Pendidikan IPA, Fakultas Keguruan dan Ilmu Pendidikan,

p-ISSN: $2527-7537$

Universitas Sebelas Maret

e-ISSN: 2549-2209

Gedung D lantai 2 FKIP

E-mail: febrianisarwendahasri@staff.uns.ac.id 


\section{INTRODUCTION}

Geoscience is the scientific study of earth, including geology, geochemist, geophysics, paleontology, and other disciplines to earth's condition in the past, present, and future. This point of view is based on the dynamic climate condition (King, 2019). Geoscience learning is not well developed in many countries. It still becomes an interesting discussion topic regarding recent research findings suggest implement a different way of teaching it. This suggestion appears because previous learning activities are not relevant to the job demand nowadays (Mikes, 2015; Neenan, 2016). Some weaknesses in geoscience teaching and learning are the unclear purpose of the study (Neenan, 2016), class basedlearning (Waldron et al., 2016), the lack of industrial demand skills (Mikes, 2015), and it is for students to gain misconceptions (King 2008). The finding from the preliminary study students tends to memorize than understanding, even though they know that basic process will guide to advance mastery of every subject.

According to Ibrahim (2012), Science and Technology development is related to conceptual understanding. It can be triggered by providing interaction between students and their everyday environment to gain various phenomenon inquiries (Haryono, 2017).

The mentioned activity will lead to conceptual mastery through experiential learning. This experiential learning includes finding concepts after finishing a set of scientific works. Scientific works are including hands-on and minds-on (Wenning, 2007). It follows these steps consecutively define the problem, state a hypothesis, design an experiment, collecting and analyzing data, present the result of the data, and making a conclusion (Etkina et al., 2006).

One of the ways to improve conceptual mastery and scientific working is through conducting skill based-learning (including using a modified daily life student environment (Waldron et al., 2016) as well as using field-based learning (Almquist et al., 2011). During fieldbased learning, proper learning material has required. The teacher needs to prepare the match learning tools for students.

To resolve the mentioned problems above, an alternative solution is needed. Such as creating students worksheets based on the constructivism approach to guide students to find their concept through scientific work. This student worksheets was created based on Geoscience course learning outcomes and to help students plan, doing, and evaluate their projects. So, after the course hopefully, students will gain concepts through their scientific work and also reflecting on what they have done in one semester.
Based on problem mentioned above, it is important for researchers to research about developing Geoscience Students Worksheets based on field-work to Improve Students Scientific Work and Concept Mastery in the validity and students response stage especially through validity and students response point of view.

\section{METHOD}

This research is Research and Development using 4D Thiagarajan (1974) model and was conducted until Develop stage. During the first stage, Define, all of the preliminary studies were done including front-end analysis to analyze the student interest, difficulties, lecturer perspective, and the demand of the curriculum both national curriculum for junior high school students and curriculum for preservice teacher's curriculum. Task and concept analysis was done to specify the student requirement based on curriculum and student interest. After specifying the task and concept, then specific learning objectives were following.

The second stage is Design, in this stage, prototype was made based on the result of previous stage. During Design stage, all speficic learning objectives then divided into some section and proper student activity then arranged in line with it. After completing all component, prototype of Geoscience Student Worksheets was made. This prototype then being validated by two exepert to obtain suggestions for revision. Some students then randomly choosen to read and give suggestion to the revised version of Geoscience Student Worksheets. This step to receive student response toward the revised version of Geoscience Student Worksheets, revision was made to fulfil the suggestion from students. Two last steps written above are in the Develop stage

\section{Research Target}

The test targets in this research are a geoscience content expert, a learning media expert, and ten student who took Geoscience course in the previous year. Both experts educational background is master of science education. The experts are validators of media and the students were respondents to gain a response from. The response including legibility, attractiveness, and what component should be added to the developed student worksheets.

\section{Data Collection Technique}

There are two data collecting techniques in this research the first technique is questionnaire and the second technique is interview. In the questionnaire there are two kinds of questions, closed ended questions to validate/to gain exact scores from the validators and open ended question for gaining information about improvement requirement. 
Similar with the validators, students questionnaire are consists of closed ended question about their response to the Geoscience Students Worksheet and the open ended question also to receive more suggestions from students point of view. Interview was conducted during Define stage (first step in this research).

There are six indicators for content expert validatior they are content completeness, content accuracy, language, contextuality, presentation, and scientific work. Furthermore for learning media expert, there are seven indicators they are desain of cover and content, course presentation, availabiluty of supporting resource, practicability, suitability the user and the activities, and suitability of the developed media with activities. Also for students, there are four indicators including language, attractiveness, content, and display of the component. Moreover, open ended question consist of question about what is strengths and weakness of the geoscience students worksheet and suggestion for improvement.

Quantitave data was analized using this following guidelines:

$$
\begin{aligned}
& \mathrm{Va}=\frac{T S h}{T S e} \times 100 \% \\
& \mathrm{Ve}=\frac{T S h}{T S e} \times 100 \%
\end{aligned}
$$

with:

$\mathrm{Va}=$ Expert validity

$\mathrm{Ve} \quad=$ Students response

$\mathrm{T}_{\mathrm{Sh}} \quad=$ Maximum score

$\mathrm{T}_{\mathrm{Se}} \quad=$ Score from experts or respondents

The result of validation then compared to Table 1 to receive the conclusion of geoscience students worksheets.

Tabel 1. Student Worksheets Validation Criteria

\begin{tabular}{ccc}
\hline No & Validity Criteria & Conclusion \\
\hline 1 & $85,01 \%-100 \%$ & $\begin{array}{c}\text { Very valid, no revision } \\
\text { required }\end{array}$ \\
\hline 2 & $70,01 \%-85 \%$ & $\begin{array}{c}\text { Valid enough, minor } \\
\text { revision required }\end{array}$ \\
\hline 3 & $50,01 \%-70,00 \%$ & $\begin{array}{c}\text { Not valid, major revision } \\
\text { required }\end{array}$ \\
\hline 4 & $01,00 \%-50 \%$ & $\begin{array}{c}\text { Not valid, can not be } \\
\text { continued to next step }\end{array}$ \\
\hline
\end{tabular}

\section{RESULTS AND DISCUSSIONS}

The result of the research are listed below:

1. Define

In this stage, researchers define the requirements for better learning, especially the learning media requirements. This stage including front-end analysis, learner analysis, task analysis, concept analysis, and specifying instructional objectives. Furthermore, some problems were found in this part of the research namely: the lack of student interest and scientific work during Geosains classes. Also, after carefully analyzed the curriculum, there were overlapping topics with another course. Another problem such as student misperception about learning is memorizing everything so that it gives impact on the students final score. During the research, learner analysis here was not explicitly analyzed due to the student's targets are common students. Task and concept analysis were done by comparing the department curriculum and national curriculum including the $21^{\text {st }}$ century demands in the learning process. Form this process, it found that some topics in the previous course are not necessarily included in the Geosains course because they have been taught in another course before such as the theory of earth formation, the earth surface, and geological history. Although it seems that all of the mentioned topics above are commonly relevant to geoscience, those topics are overlapping with another course. However, Geosains here firmly refers to weathering, especially due to physics, chemist, and biological agents. Moreover, after finding the concept problem and the proper concept, tasks were arranged. The Task here including doing a project to explore why weathering happens and how to protect stone based artefacs. In this project, students explore the cause of weathering, how to minimize the effect of weathering and possible ways to minimize the weathering process through scientific reading and proposing ideas. The last process is specifying instructional objectives. All needed activities described above then are transcribed into specific indicators.

2. Design

In this stage, the researcher focus on designing a prototype of the media. There are three important steps during this stage, they are media selection, format selection, initial design. During media and format selection, according to the result of the Define stage, it was concluded that in the worksheets it has to have section for the field project, reflecting the project, and write down the concept from students during the project. Also, misconception and the correct concept have to be written explicitly in the student worksheets. These parts are important because the main purposes of this student's worksheets are to improve student scientific work and concepts understanding. Sometimes, during a project, students find the wrong concept. By comparing them, hopefully, it will help them 
to understand the concept last longer. The media being selected in this research is Students Worksheets. In the worksheets, there are cover, preface, and learning idicators. In the main content, there are 4 different chapters. First chapter consists of review of student prior knowledge, second chapter consists of a project to investigate why do the stone weathering. This project is a group project, and every week, the group scientific work are being monitored through several question in the students worksheets, from finding a problem until concluding the research. In the chapter 3, there is another project. The project is preventing the stone-based artifact from weathing. The same as with previous project, there are reflection in every stage of scientific working in every steps of their work. Chapter 4 consists of many scientific articles where students can gain information from. Through this reading activity, student read and write the main concept according to core concepts of the course, identify what they found during the project and compare it to the scientific articles. There are spaces for student to write the wrong and correct concepts. In the end of the students worksheets is references.

3. Develop

During develop stage, the expert appraisal step is including validating and obtaining suggestions for improvement of the media. There were two validators in this step, they are learning media and content validator. The result of the content validator is shown in Table 2 below.

Table 2. The Result of Validity Testing from Content Expert

\begin{tabular}{llc}
\hline No & Aspect & Precentage \\
\hline 1 & $\begin{array}{l}\text { Content } \\
\text { Completeness }\end{array}$ & $85 \%$ \\
\hline 2 & Content Accuracy & $86,36 \%$ \\
\hline 3 & Language & $91,67 \%$ \\
\hline 4 & Contextuality & $100 \%$ \\
\hline 5 & Presentation & $91,67 \%$ \\
\hline 6 & Scientific work & $85,41 \%$ \\
\hline & Total & $90,01 \%$ \\
\hline
\end{tabular}

There are six indicators used in testing the validity of Geoscience Student Worksheets, which is shown in Table 2 above. The highest score is in the contextuality aspect and the lowest score is content completeness. Since the contextuality aspect gets the highest score, it means that the presented contents in the student worksheets are related to students's real life phenomenon, in contrast, the lowest score was given to the content completeness. Several suggestions were given by the validator in this aspect, including to specify the meaning of scientific work in the worksheets, giving more comment space, give more specific indicators in every activities, giving picture credit to the embedded pictures in the worksheets too. The validator also gives comment that the "Geoscience" term has to be strictly defined before entering the main content of the student's worksheets to make sure that students are not misinterpret the definition of geoscience.

This Geoscience Student Worksheets was also validated by the learning media expert and the result can be seen in Table 3 .

Tabel 3. The Result of Validity Testing from Learning Media Expert

\begin{tabular}{llc}
\hline No & \multicolumn{1}{c}{ Aspect } & Precentage \\
\hline 1 & Cover design & $80 \%$ \\
\hline 2 & Content design & $85,36 \%$ \\
\hline 3 & Course presentation & $87,67 \%$ \\
\hline 4 & $\begin{array}{l}\text { Availabiluty of supporting } \\
\text { resource }\end{array}$ & $87,5 \%$ \\
\hline 5 & Practicability & $84,56 \%$ \\
\hline 6 & $\begin{array}{l}\text { Suitability the user and the } \\
\text { activities }\end{array}$ & $85,41 \%$ \\
\hline 7 & $\begin{array}{l}\text { Suitability of the developed } \\
\text { media with activities }\end{array}$ \\
\hline \multicolumn{1}{c}{ Total } & $85 \%$ \\
\hline \multicolumn{2}{c}{$85,07 \%$} \\
\hline
\end{tabular}

As seen in Table 3, the highest score is course presentation because all of the components in the Geoscience Students Worksheets is well documented, including there is space for students for writing and analyzing student's misconception. On the other hand, the lowest score is cover design due to lack of color contrast and unclear title so that the cover does not describe the worksheets content appropriately.

After revising the Geoscience Students Worksheets, the worksheets is then being read by the student to obtain their response to it and the result is shown in the Table 4.

Table 4. The Result of Student Response Test

\begin{tabular}{|c|c|c|}
\hline No & Aspect & Precentage \\
\hline 1 & Language & $90,70 \%$ \\
\hline 2 & Attractiveness & $86,67 \%$ \\
\hline 3 & Content & $90,25 \%$ \\
\hline 4 & Display & $90,26 \%$ \\
\hline & Total & $89,47 \%$ \\
\hline
\end{tabular}

According to the result research, it was found that the highest score is in the language aspect. It shows that the Goeoscience Student's Worksheets is easy to understand by students $(90,70 \%$ ) (Table 4). This high language score similar to the validation result from the content expert $(91,67 \%)$ (Table 2). On the other hand, the lowest is in attractiveness. This finding is relevant to the validation result from learning media experts 
$(86,67 \%$ from students and $87,67 \%$ from learning media expert), which means that design aspects need to be improved.

The other aspect, content, from students is $90,25 \%$ (Table 4) when the content validity give $85 \%$ (Table 2) for content completeness and accuracy $86,36 \%$ (Table 2). This may because the written content in the Geoscience Students Worksheets is concise and clear for students. Display aspect is the second lowest score, $89,4 \%$ (Table 4), the learning media validator also give the similar result, $80 \%$ (Table 3 ) in conver design and $85,36 \%$ (Table 3 ) in course presentation, so that this aspect also need some revision.

The result of validations from both validators and students's response show that this Geoscience Students Worksheets is very valid. They are $90,01 \%$ (Table 2) from content validator, $85,07 \%$ (Table 3) from learnig media validator, and $89,4 \%$ (Table 4) from students.

Aspect cover design is still low in learning media expert score due to the size and the type of the font that being used in the cover of Geoscience Students Worksheets. In the Geoscience Students Worksheets there are some parts where the written font is too small or use too complicated font style, whereas people tend to remember the bigger size of the font (Halamish et al., 2018) and easy to read font (Nakahata et al., 2016; Dressler, 2019).

Beside the font size and style, the others factor that contibute to the low score of design both from students and learning media validators is the color. Some of the background color in the Geoscience Student Worksheet is cold tonned color, which can decrease the speed of reading (Rello, L., \& Jeffrey, P.B., 2017; Aslan, Y. 2019) and also the retention rate od graduate (Oluwakemi \& Tayo, 2015).

The content of the Geoscience Students Worksheets is very valid through the expert validation. This result is because the activities provided in the Student Worksheets facilitated students to create new concept. Students will develop new concepts through activities will grow students gradual understanding (Vosniadiu, 2019).

The cover design is shown in the Figure 1 below. In the the are some components such as the title, writers, illustration, and affiliation.

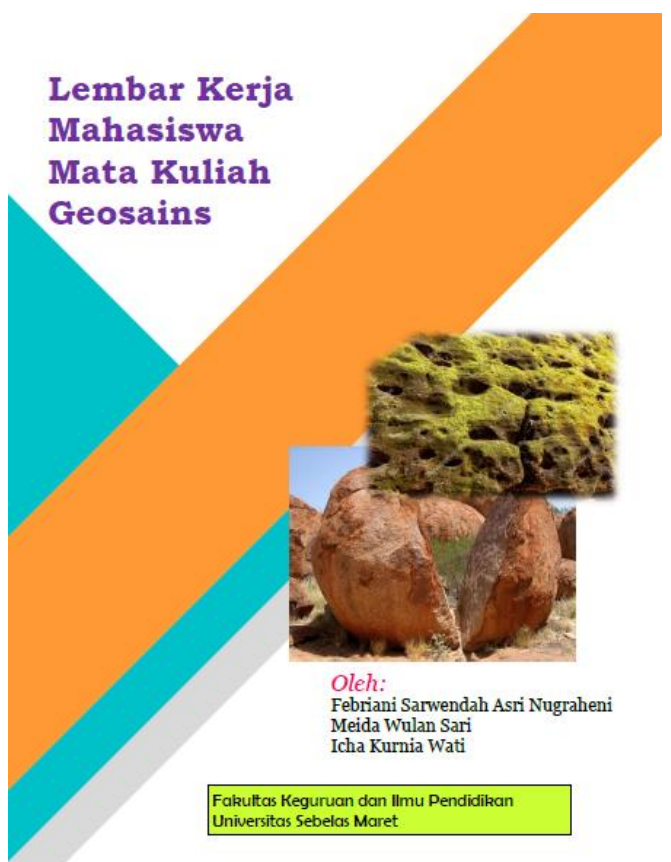

Figure 1. Cover of Geoscience Students Worksheets

\section{CONCLUSION AND SUGGESTION}

\section{Conclusion}

According to the reseach result it can be concluded that the Geoscience Students Worksheets is very valid from validator of content, validator of learning media, and from the students response. The score consecutively are $90,01 \%$, 85,07\%, dan 89,4\%. This Geoscience Students Worksheets is can be continued to test it's effectivity in a real class learning.

\section{Suggestion}

It is recommended for other researchers to entangle more expert in developing learning 
media, including practitioner in the related field, using more features in the Geoscience Students Worksheets, and invite more students to participate in the students response test.

\section{REFERENCES}

Almquist, H., George, S., Lisa, B., Marc., Megan, R., Seymour, H., \& Jeffrey, C.2011. An integrated field-based approach to building teachers' geoscience skills. Journal of Geoscience Education, Vol. 59, No. 1, pp. 31-40.

Aslan, Y. (2019). Effects of backgroun colors on Reading Speed. Diunduh pada Tanggal 25 Juni 2021, dari https://www.researchgate.net/publication/3 30514314_Effects_of_Background_Colors _on_Reading_Speed

Dressler, E., 2019. Understanding the Effect of Font Type on Reading Comprehension/Memory under TimeConstraints. United States of America: University of Nebraska Omaha.

Etkina, E., Van Heuvelen, A., White-Brahmia, S., Brookes, D.T., Gentile, M., Murthy, S., Rosengrant, D.\& Warren,. A. 2006. Scientific abilities and their assessment. Physics Education Research. Vol. 2 No. 2, pp. 1-15.

Halamish, V., Hila, N., Tami, K. 2018. The Effect of font size on children's memory and Metamemory. Frontiers in Psychology, Vol. 9 No. 1577, pp. 1-9.

Haryono, Setyo. 2016. Peningkatan keterampilan kerja ilmiah siswa kelas $\mathrm{X}$ melalui model pembelajaran inquiry role approach berbasis lesson study di SMAN 16 Semarang. Bioma, Vol. 6 No. 2, pp. 66-77.

Ibrahim, Muslimin. 2012. Konsep, miskonsepsi, dan cara pembelajarannya. Indonesia: Unesa University Press.

King, C. 2008. Geoscience education: an overview. Studies in Science Education. Vol. 44 No. 3, pp. 187-222.
Mikes, D. 2015. Geoscience education is outdated. South African Journal of Geology, Vol. 188 No. 3, pp. 299-301.

Nakahata, S., Emiko, S., Akiho, O., Noriko, K., Sho, S. 2016. Effects of color of book cover and typeface of title and author name on gaze duraion and choice behavior for books: Evidence from an eye-tracking experiment. Proceedings of the Association for Information Science and Technology, Vol. 53, No. 1, pp. 1-4.

Neenan, E., E. 2016. Geoscience Education in an Iris Context: A Need for Research. Journal of Geoscience and Environment Protection. Vol. 4, pp. 1-8.

Olurinola, O. \& Tayo, O. 2015. Colour in Learning: It's effect on the retention rate of graduate students. Journal of Education and Practice, Vol. 6 No. 14, pp. 1-5.

Rello, L., \& Jeffrey, P.B. (2017). Good background colors for Readers: A Study of People with and Without Dyslexia. Diunduh pada Tanggal 25 Juni 2021, dari https://www.cs.cmu.edu/ jbigham/pubs/pd fs/2017/colors.pdf.

Thiagarajan, S., Semmel, D., Semmel., M. 1974. Instructional development for training teachers of exceptional children A sourcebook. USA: Center for Innovation in Teaching the Handicapped Indiana University Bloomington, Indiana.

Vosniadou, S,. 2019. The development of student' understanding of science. Frontiers in Education, Vol 4. No.32, pp. 1-6.

Waldron, J., W., F., Andrew, J., L., \& Anna, P., B.. 2016. Building an outdoor classroom for field geology: the geoscience garden. Journal of Geoscience Education, Vol 64, pp. 215-230.

Wenning, C., J. 2011. Experimental inquiry in introductory physics courses. Journal Physics Teacher Education Online, Vol. 6 No. 2, pp. 2-8." 